\title{
10
}

\section{USES AND ABUSES OF REFUGEE HISTORIES}

\author{
Klaus Neumann ${ }^{1}$
}

In recent years, scholars with an interest in the history of refugee policies have often noted the lack of historical analysis in discussions of current issues of forced displacement. ${ }^{2}$ Such complaints are increasingly unfounded. In scholarly debates about displacement and protection, and in discussions about public policy, historians and their skills are now sought after rather than ignored. The discipline of history has become an essential part of what is variously called forced migration studies or refugee studies. This collection is but one of several recent edited books

\footnotetext{
1 The research for this paper was partially funded by the Australian Research Council (DP160101434). The research for and writing of this chapter was completed in 2018.

2 See, for example, Tony Kushner, Remembering Refugees: Then and Now (Manchester: Manchester University Press, 2006), 1; Philip Marfleet, 'Refugees and History: Why We Must Address the Past', Refugee Survey Quarterly 26, no. 3 (2007): 136-48, doi.org/10.1093/rsq/hdi0248; Peter Gatrell, 'Refugees - What's Wrong with History?' Journal of Refugee Studies 30, no. 2 (2017): 170-89. In 2006, Martin Jones analysed the profiles of staff and doctoral students of the four leading centres for refugee research at the time and found that only four out of 121 researchers self-identified as historians. See Martin Jones, 'Review of Refuge Australia: Australia's Humanitarian Record', Refuge 23, no. 1 (2006): 104 n. 21, doi.org/10.25071/1920-7336.21348. Many of those then writing about the silence of the historical profession, myself included, identified as historians and were busily contributing historical analyses to refugee studies; see, for example, Klaus Neumann, 'Refugees: The Silence of the Historians', Age, 11 June 2004, available at: www.theage.com.au/national/refugees-the-silence-of-the-historians20040611-gdy0ic.html.
} 
and special issues that attest to this trend. ${ }^{3}$ Historians are also increasingly comparing and contrasting current and past responses to refugees. In 2018, for example, Pertti Ahonen and Tony Kushner compared British public responses to the 1938 German and Austrian refugee crisis with those to the mass arrival of refugees in Europe in 2015 and 2016. ${ }^{4}$ While there is broad agreement that the origins of the current refugee regime lie in the early twentieth century, even historians specialising in earlier times have been able to convincingly relate their research to twenty-firstcentury questions. Elena Isayev, Benjamin Gray and Susanne Lachenicht, for example, have recently discussed practices up to two millennia apart, and highlighted the relevance of a study of responses to strangers in the ancient Greek and Roman worlds and in early modern Europe for a critical understanding of current issues. ${ }^{5}$

There are many reasons why historians investigate past responses to forced migration. Some do so because they expect their analyses to contribute to an understanding of topical issues or provide evidence in support of particular strategies for addressing these issues. Some believe that other historical developments need to be reinterpreted in the contemporary context of forced migrations. Others have identified refugee history as a field that thus far has attracted comparatively little academic research, and which therefore still offers plenty of opportunities for scholars to make their name. It is not my intention to deem some motivations worthier than others; rather, I wish to point out that there is a wide range of reasons that compel historians to be interested in refugee issues. By

3 Matthew Frank and Jessica Reinsch, eds, Refugees in Europe, 1919-1959: A Forty Years' Crisis? (London: Bloomsbury, 2017); Peter Gatrell and Liubov Zhvanko, eds, Europe on the Move: Refugees in the Era of the Great War (Manchester: Manchester University Press, 2017); Fernando Puell de la Villa and David García Hernán, eds, War and Population Displacement: Lessons of History (Brighton: Sussex Academic Press, 2018); J Olaf Kleist, ed., History of Refugee Protection, special issue, Journal of Refugee Studies 30, no. 2 (2017); Dan Stone, ed., Refugees Then and Now: Memory, History and Politics in the Long Twentieth Century, special issue, Patterns of Prejudice 52, no. 2-3 (2018).

4 Pertti Ahonen, 'Europe and Refugees: 1938 and 2015-16', Patterns of Prejudice 52, no. 2-3 (2018): 135-48, doi.org/10.1080/0031322x.2018.1433006; Tony Kushner, 'Truly, Madly, Deeply ... Nostalgically? Britain's On-Off Love Affair with Refugees, Past and Present', Patterns of Prejudice 52, no. 2-3 (2018): 172-94, doi.org/10.1080/0031322x.2018.1433014.

5 Elena Isayev, 'Between Hospitality and Asylum: A Historical Perspective on Displaced Agency', International Review of the Red Cross 99, no. 1 (2017): 75-98, doi.org/10.1017/s1816383117000510; Benjamin Gray, 'Exile, Refuge and the Greek Polis: Between Justice and Humanity', Journal of Refugee Studies 30, no. 2 (2017): 190-219, doi.org/10.1093/jrs/few027; Benjamin Gray, 'Citizenship as Barrier and Opportunity for Ancient Greek and Modern Refugees', Humanities 7, no. 3 (2018): 72, doi.org/10.3390/h7030072; Susanne Lachenicht, 'Learning from Past Displacements? The History of Migrations between Historical Specificity, Presentism and Fractured Continuities', Humanities 7 , no. 2 (2018): 36, doi.org/10.3390/h7020036. 
comparison, public interest in the history of forced displacement tends to be prompted by the idea that history had either or both of two functions: to provide lessons and/or to make sense of the present.

Those looking for lessons expect historians to tell them about possible courses of action that ought to be avoided (because similar courses of action proved to be harmful or unsuccessful in the past), and others that should be pursued (because comparable approaches proved beneficial or were successful in earlier times). Such expectations are informed by the assumption that the past and the present are sufficiently similar to transfer insights gained by studying the former to the latter. Historians are partly to blame for this misconception. In order for their work to be considered socially useful, some of them refer to the past as if it were a repository of precedents. ${ }^{6}$ The search for lessons is also guided by the illusion that human beings would be inclined to make rational decisions based on precedent if only they knew enough about the past. This is surprising because there is ample evidence to suggest that humankind has not been inclined to desist from repeating harmful courses of action. ${ }^{7}$

Many historians also claim that their discipline allows them to situate the present on a linear trajectory that reaches from the past to the future. Take, for example, the webpage of Monash University's History Program, which tells prospective students that 'historical studies tells us where we came from, who we are, and where we're heading. ${ }^{8}$ Or take the eminent social historian Peter Stearns, who, in a 1989 document published on the website of the American Historical Association, says: 'History helps us understand change and how the society we live in came to be ... The past causes the present, and so the future.'

6 For example, Jo Guldi and David Armitage, The History Manifesto (Cambridge: Cambridge University Press, 2014).

7 See, for example, Bill Fawcett, ed., Doomed to Repeat: The Lessons of History We've Failed to Learn (New York: William Morrow, 2013).

8 'History', School of Philosophical, Historical and International Studies, Monash University, available at: www.monash.edu/arts/philosophical-historical-international-studies/history.

$9 \quad$ Peter N Stearns, 'Why Study history?', American Historical Association, 1998, available at: www. historians.org/about-aha-and-membership/aha-history-and-archives/historical-archives/why-studyhistory-(1998). In the text published by the American Historical Association, the first sentence of this quote has been capitalised, but this appears to be a formatting error. 
Narratives that supposedly tell us 'where we came from [and] who we are' are often used to underwrite particular policies and practices in the present. The more coherent and seamless the narratives are, the better they are suited for such a purpose. In Australia, the narrative that more than any other has been employed to shore up current responses to refugees and asylum seekers depicts Australia as a traditionally generous and compassionate society. Australian governments have repeatedly used this narrative domestically to suggest that current policies and practices ought to be seen as yet another instantiation of generosity and compassion, as if a break with a supposedly long-established tradition was inconceivable. ${ }^{10}$

The claim that Australia has always been generous and compassionate could also be used to dismiss criticism of specific instances in which Australia's approach is characterised by a lack of generosity and compassion. The following example illustrates this point. A report by the Special Rapporteur on Torture and Other Cruel, Inhuman or Degrading Treatment or Punishment, which was tabled at the 37th session of the United Nation's Human Rights Council (to which Australia had just been elected for three years) in February 2018, observed that, in response to the arrival of increasing numbers of irregular migrants:

many States have initiated an escalating cycle of repression and deterrence to discourage new arrivals involving measures such as the criminalization and detention of irregular migrants, the separation of family members, inadequate reception conditions and medical care and the denial or excessive prolongation of status determination or habeas corpus proceedings, including expedited returns in the absence of such proceedings. Many States have even started to physically prevent arrivals, whether through border closures, fences, walls or other physical obstacles, through the externalization of their borders and procedures or extra-territorial 'pushback' and 'pullback' operations, often in cooperation with other States or even non-State actors. ${ }^{11}$

10 See, for example, in relation to Australian refugee and asylum seeker policies: Klaus Neumann, 'Oblivious to the Obvious? Australian Asylum-Seeker Policies and the Use of the Past', in Does History Matter? Making and Debating Citizenship, Immigration and Refugee Policy in Australia and New Zealand, ed. Klaus Neumann and Gwenda Tavan (Canberra: ANU E Press, 2009), 59-60, doi.org/10.22459/ dhm.09.2009.03.

11 Nils Melzer, Report of the Special Rapporteur on Torture and Other Cruel, Inhuman or Degrading Treatment or Punishment, UN Doc A/HRC/37/50 (23 November 2018) para 7. 
In conclusion, the report noted that the primary cause for the abuse suffered by migrants was neither migration itself nor organised crime, but rather states' growing tendency 'to base their official migration policies and practices on deterrence, criminalization and discrimination rather than on protection, human rights and non-discrimination'. ${ }^{12}$

It is common for the authors of such reports to be coy about the identity of state parties, and hence it is unsurprising that the report did not mention Australia. In fact, it did not name any of the 47 members of the Human Rights Council, which then included countries that have a human rights record far worse than Australia's, such as Kyrgyzstan and China. Yet Australia’s foreign minister, Julie Bishop, felt sufficiently provoked by the report's veiled criticism to counter it by a reference to history:

There are many who believe that what we have done in turning back the boats and imposing very strong border protection laws is the right thing to do ... What we are doing is what every sovereign government should do - protect our borders and determine our immigration flows. Australia has one of the proudest records of bringing in refugees. Since the Second World War, 865,000 people have come to Australia on refugee and humanitarian visas. Every year we resettle 18,750 people on refugee visas. We've taken 12,000 additional refugees from Syria. It is a record that Australians should be proud of and it is certainly one that I am prepared to have scrutinised by the Human Rights Council and any other nation around the world. ${ }^{13}$

Bishop wielded history as a weapon, although she had not been called upon to respond to somebody else's interpretation of Australia's past. Her position is remarkably similar to that of some refugee advocates who have also suggested that Australia was traditionally generous. Rather than using a record of past generosity to gloss over current failings, or implying that strong border protection laws are a necessary corollary, some refugee advocates have characterised the present as an aberration, while otherwise agreeing with the kind of narrative offered by Bishop, and its patriotic premises. ${ }^{14}$

12 Ibid., para 66.

13 Julie Bishop, interview with Fran Kelly on $A B C$ RN Breakfast, 27 February 2018, available at: www.foreignminister.gov.au/minister/julie-bishop/transcript-eoe/abc-rn-breakfast-interview-frankelly- 0 . Bishop responded to the report's advance unedited version.

14 For example, Klaus Neumann, 'Providing a "Home for the Oppressed"? Historical Perspectives on Australian Responses to Refugees', Australian Journal of Human Rights 9, no. 2 (2003): 1-2, doi.org/ 10.1080/1323238x.2003.11911103. 
Elsewhere I have critiqued the idea that Australia has been traditionally generous when responding to refugees and asylum seekers, without, however, trying to suggest that the grand narrative about Australia's generosity needs to be replaced by one about Australian racism, fear of the other and lack of hospitality. ${ }^{15}$ Here, I would like to take a different tack and briefly tell three stories that could disrupt grand narratives that tell us 'where we came from, who we are, and where we're heading. They are also useless in that they don't provide ready-made lessons for the present.

As I began writing this chapter, newspapers around the world were drawing attention to the 80th anniversary of the Évian conference, which had been initiated by US President Franklin Roosevelt. ${ }^{16}$ From 6 to 15 July 1938, the representatives of 32 countries - 10 from Europe, 20 from the Americas, and Australia and New Zealand - met in Évian-les-Bains on the shores of Lake Geneva to discuss the Jewish refugee crisis. The conference became notorious because it was spectacularly unsuccessful. The Dominican Republic, then led by the dictator and Hitler admirer Rafael Trujillo, was the only one of the countries represented at the French spa that offered to admit a contingent of Jewish refugees. ${ }^{17}$ All other countries were determined to keep their borders closed, or at least not to increase their intake of refugees.

One statement more than any other has come to symbolise the supposed lack of compassion for refugees. The Australian delegate Thomas Walter White, the minister for trade and customs in the conservative Coalition Government of Joseph Lyons, said that: 'It will no doubt be appreciated also that as we have no real racial problem, we are not desirous of importing

15 Klaus Neumann, Refuge Australia: Australia's Humanitarian Record (Sydney: UNSW Press, 2004).

16 About the conference, see, most recently, Paul R Bartrop, The Evian Conference of 1938 and the Jewish Refugee Crisis (Cham: Palgrave Macmillan, 2018); Raphaël Delpard, La conference de la honte: Evian, juillet 1938 (Paris: Michalon, 2015); Jochen Thies, Evian 1938: Als die Welt die Juden verriet (Essen: Klartext, 2017). See also Wolfgang Benz, Claudio Curio and Heiko Kauffmann, eds, Von Evian nach Brüssel: Menschenrechte und Flüchtlingsschutz 70 Jahre nach der Konferenz von Evian (Karlsruhe: Loeper, 2008), which brings together a discussion of the Évian conference and a discussion of asylum in the early twenty-first century.

17 About the racism that informed Trujillo's decision, and the outcome of his offer, see Hans-Ulrich Dillmann and Susanne Heim, Fluchtpunkt Karibik: Jüdische Emigranten in der Dominikanischen Republik (Berlin: Ch. Links Verlag, 2009). 
one by encouraging any scheme of large-scale foreign migration'. ${ }^{18}$ These words are regularly quoted when the Évian conference is mentioned, particularly in the context of discussions about current responses to refugees and asylum seekers, not just in Australia. They are also prominently displayed at the Yad Vashem Holocaust memorial in Israel.

In Australia, at least, the position of the Australian Government at Évian was initially not widely perceived as problematic, not least because a critical account would have sat uneasily within a narrative emphasising 'traditional' Australian generosity. In 1976, New South Wales Liberal Senator Peter Baume said in the Senate:

I cannot forget that in 1938 there was a conference at a town called Evian and that Australia was one of the few nations in the world willing to give entry permits to the refugees of those days ... We established then the kind of honourable tradition in matters of refugees of which I am very proud. ${ }^{19}$

More recently, however, embarrassment about White's words prompted Stuart Robert, a Liberal National Party politician who represents the Queensland seat of Fadden in Federal Parliament, to put forward a motion that condemned the indifference of White and the Lyons Government, and included an apology, although its addressee was not specified:

Today this parliament, as representative of all political parties and the people of Australia, issues a profound apology and says sorry to the people for the indifference shown by the parliament in 1938 that worsened the impact of the Holocaust. ${ }^{20}$

The motion, which had bipartisan support, also suggested that a request be made to the Yad Vashem memorial authority to have the text of the parliamentary apology displayed next to White's words. The apology and the proposed plaque could be interpreted as an attempt to restore Australia's reputation as a caring nation, rather than as a form of symbolic reparation.

18 T W White, quoted in Intergovernmental Committee on Refugees, Proceedings of the Intergovernmental Committee, Evian, July 6th to 15th, 1938: Verbatim Record of the Plenary Meetings of the Committee: Resolutions and Reports (Chambéry: Imp. réunies de Chambéry, 1938), 20.

19 Commonwealth, Parliamentary Debates (hereafter: CDP), Senate, 19 October 1976, 1271 (Peter Baume). Baume made a similar claim four years later: CPD, Senate, 27 August 1980, 441 (Peter Baume).

20 CDP, Representatives, 26 March 2018, 2613 (Stuart Robert). 
I would like to suggest that moral indignation about White's words, which are taken to be emblematic of Australian indifference towards the plight of German and Austrian Jewish refugees, usually thwarts a closer look at what happened at Évian and in its aftermath. What could such a look entail? For a start, it should be remembered that the delegates at Évian could not have known what we know today, namely that 6 million Jews were murdered in the Holocaust. Unlike most of today's public commentators writing about the Évian conference, contemporary observers did not believe that the situation of Jews in Germany was the only pressing issue. A preliminary report published by John Hope Simpson in July 1938 to inform international diplomatic discussions identified the imminent danger of new refugee movements' ${ }^{21} \mathrm{He}$ did not only have Germany and Austria in mind but also countries in Eastern Europe, particularly Poland and Romania, whose governments were openly anti-Semitic, and Spain. Hope Simpson did not believe that large-scale international resettlement schemes were a realistic answer to the situation in Eastern and South-Eastern Europe.

White represented Australia at Évian not because he was responsible for Australia's immigration policy but because he happened to be in Europe at the time as part of a high-level delegation that tried to negotiate a new trade deal with the United Kingdom. While it is true that some of those responsible for Australian refugee policies and some key staff in the relevant government agency, the Department of the Interior (the immediate predecessor of the Department of Immigration), were anti-Semitic, the same could not be said of White. It is also true that the government of avowed pacifist Joseph Lyons supported an appeasement strategy towards the German Reich, but White himself was not in favour of appeasement. ${ }^{22}$ He was also not a sympathiser of Nazi Germany. Before arriving in Évian, he toured Germany as a guest of the German Government 'to learn something of its present state under the Hitler regime', as he put it in his diary. ${ }^{23} \mathrm{He}$ admired the new Tempelhof airport and enjoyed a night at the opera, but otherwise was appalled by what he recognised as signs of a ruthless dictatorship. In a letter after his return to Australia, White

21 John Hope Simpson, Refugees: Preliminary Report of a Survey (London: Royal Institute of International Affairs, 1938), 190.

22 Christopher Waters, Australia and Appeasement: Imperial Foreign Policy and the Origins of World War II (London: I.B. Tauris, 2012), 94.

23 Thomas Walter White, '1938 Overseas Diary TWW', entry for 1 July 1938, Sir Thomas Walter White papers, National Library of Australia MS 9148, series 7, folder 41. 
wrote that Germany was marked by 'regulations, restrictions, uniforms and hidden terrorism'. ${ }^{24}$ His observations contrasted with those of his United Australia Party and Cabinet colleague Robert Menzies, whose views of the Nazi regime were ambivalent; he too had been a member of the Australian trade delegation in the United Kingdom and had visited Germany in July $1938 .^{25}$

In his speech at the Évian conference, White said that Australia would not admit additional migrants from Europe, but as chair of the SubCommittee on the Reception of Those Concerned with the Relief of Political Refugees from Germany including Austria, he sought the views of NGOs assisting refugees. The document that reports the findings of that sub-committee recognised that the situation of German and Austrian Jews was desperate.

White attended only the first four days of the 10-day diplomatic gathering at Évian and then returned to Australia; he had no direct say in the outcome of the conference. In any case, White was not the driving force behind Australia's eventual response to the persecution of German and Austrian Jews. The man who more than anybody else influenced that response was the former Australian prime minister and then high commissioner in London, Stanley Melbourne Bruce. He had represented Australia at the League of Nations and would have been a more obvious choice as leader of the Australian delegation. He too visited Évian in the second week of July 1938 - not in an official capacity but 'incognito', to consult with Alfred Stirling, a senior London-based diplomat who led the Australian delegation after White's departure. It is not known what Stirling and Bruce discussed.

Three months before the Évian conference, Bruce had warned the Australian Government to avoid gestures that might encourage mass expulsions of Jews from Eastern European countries. ${ }^{26}$ However, in November 1938, a couple of weeks after the Reichskristallnacht pogroms in Germany and Austria, he convinced the Australian Government (which by then

24 White to Atchison, 10 October 1938, quoted in Christopher Waters, 'Understanding and Misunderstanding Nazi Germany: Four Australian Visitors to Germany in 1938', Australian Historical Studies 41, no. 3 (2010): 375, doi.org/10.1080/1031461x.2010.493950.

25 See Waters, 'Understanding and Misunderstanding Nazi Germany', 348-69; Rowan Cahill, 'A Forgotten Address', Overland, 15 June 2017, available at: overland.org.au/2017/06/a-forgottenaddress/.

26 Stanley Melbourne Bruce to Prime Minister of Australia, 5 April 1938, National Archives of Australia (hereafter: NAA) A981, REF 4 PART 1. 
no longer included White) to announce the establishment of a quota for refugees. ${ }^{27}$ Bruce wanted a quota of 30,000 over three years; the Lyons Government agreed to half that number. While the government's instructions about the composition of that quota were problematic, ${ }^{28}$ the quota itself was comparatively generous - not in relation to the overall need for resettlement places, but when compared with the number of German and Austrian refugees admitted in other non-European countries such as Canada and New Zealand. The decision of the Lyons Government in 1938 also compares favourably with the Australian response to other refugee crises, including the Syrian refugee crisis of $2015 .{ }^{29}$

A nuanced account that highlights the contradictory behaviour of historical actors, does not view the past through the telescope of the present and is attentive to the possibility that much of the past is unknowable, has little value for commentators who winnow the past for lessons or are primarily interested in genealogies. A simplistic narrative about the Évian conference allows the drawing of parallels between Western nations' responses to refugees in 1938, and the global North's response to refugees in the past few years. The Évian conference is interpreted as a precedent with catastrophic consequences, suggesting that the global North's current policies of containment and deterrence might have similar results. Such a narrative implies that those meeting at Évian were somehow responsible for the Holocaust. While the governments of some of the countries represented at Évian - for example, France and Hungary - later aided and abetted in the Jewish genocide, it was Germany, rather than the 32 countries that sent delegations to Évian, that was responsible for the Holocaust.

27 Stanley Melbourne Bruce to Prime Minister of Australia, 21 November 1938, NAA A433, $1943 / 2 / 46$. White had resigned as minister on 8 November 1938, after learning that he had been demoted in a Cabinet reshuffle. See John Rickard, 'White, Sir Thomas Walter (1888-1957)', Australian Dictionary of Biography, 2002, available at: adb.anu.edu.au/biography/white-sir-thomaswalter-12013.

28 See Klaus Neumann, Across the Seas: Australia's Response to Refugees: A History (Melbourne: Black Inc., 2015), 38-39.

29 In 2015, the Abbott Government agreed to the resettlement of 12,000 refugees from Syria and Iraq - comparatively fewer than the 15,000 refugees over three years announced in 1938, both when considering the number of Syrians requiring resettlement (compared to the number of Austrians and Germans requiring resettlement in 1938), and when considering the size of the Australian population in 1938, compared to its size in 2015 . 
Countries in the global North have long tried to draw on colonies or former colonies to warehouse refugees. For example, since at least 2004, Italian governments have tried to reach agreements with their Libyan counterparts to prevent migrants in Libya from crossing the Mediterranean. As a result of the most recent agreement, signed between Italy and its former colony on 2 February 2017 and subsequently backed by the European Union, Italy has trained and funded Libyan militias to operate a so-called coastguard to intercept migrants at sea and return them to Libya, where they are kept in detention centres and exposed to human rights violations, including murder, rape and torture. ${ }^{30}$ There are other examples. In 1940 the British deported Jewish refugees from Palestine to Mauritius. ${ }^{31}$ In 1972 the Heath Government was hoping to be able to settle Indian Ugandan refugees in the Solomon Islands. ${ }^{32}$ The US Government has used its Cuban possession Guantanamo Bay to detain Haitian and Cuban refugees. ${ }^{33}$ The most infamous recent example is that of Australia, and its use of two former territories, Papua New Guinea and Nauru, to establish so-called regional processing centres to incarcerate asylum seekers and refugees.

Much like Thomas Walter White's much-quoted sentence about his government's decision not to invite large-scale immigration has been used to establish a genealogy reaching from 1938 via 1992 (the introduction of mandatory detention) and 2001 (the Tampa affair) to the present, a line might be drawn from the exploitation of formerly phosphate-rich Nauru under Australian colonial rule to the use of impoverished postcolonial Nauru as a kind of twenty-first-century penal colony. ${ }^{34}$ In this genealogy,

30 Andrea de Guttry, Francesca Cappone and Emanuele Sommario, 'Dealing with Migrants in the Central Mediterranean Route: A Legal Analysis of Recent Bilateral Agreements Between Italy and Libya, International Migration 56, no. 3 (2018): 44-60, doi.org/10.1111/imig.12401. The Italian approach has to be seen within broader European attempts to prevent irregular migrants from reaching Europe and to set up facilities to hold, and possibly process, non-European asylum seekers in countries outside Europe. See David Scott FitzGerald, Refuge Beyond Reach: How Rich Democracies Repel Asylum Seekers (New York: Oxford University Press, 2019), Chapter 9, doi.org/10.1093/ oso/9780190874155.001.0001.

31 Geneviève Pitot, Le shekel mauricien: L'histoire des détenus juifs à l'âle Maurice: 1940-1945 (Port Louis: Vizavi, 2014).

32 Klaus Neumann, “Our Own Interests Must Come First”: Australia’s Response to the Expulsion of Asians from Uganda', History Australia 3, no. 1 (2006): 10.12, doi.org/10.2104/ha060010.

33 Azadeh Dastyari, United States Migrant Interdiction and the Detention of Refugees in Guantanamo Bay (Cambridge: Cambridge University Press, 2015), doi.org/10.1017/cbo9781316181584.

34 For a recent example, see Julia C Morris, 'Violence and Extraction of a Human Commodity: From Phosphate to Refugees in the Republic of Nauru', The Extractive Industries and Society 6, no. 4 (2019): 1122-33, doi.org/10.1016/j.exis.2019.07.001. 
Nauruans feature only as extras: they are coerced into surrendering their island to allow the mining of phosphate, and have little choice but to agree to Australia's request to accommodate asylum seekers and refugees, now that Nauru's assets have been depleted. Here, I would like to disrupt this genealogy with a story featuring Nauruan agency and Australia's willingness to take responsibility for the displacement of the atoll's population.

In 1960, Dudley McCarthy, a senior Australian bureaucrat, visited Nauru to reassure Nauruans that Australia would find a new home for them once Nauru's phosphate had been exhausted (and the atoll had become uninhabitable as a result of the mining operations). ${ }^{35} \mathrm{He}$ told representatives of the then 2,600 indigenous Nauruans on behalf of the Australian Government:

We ask you to live with us; to become part of us and to allow us to become part of you; to accept completely and absolutely without reservations of any kind all the privileges which we ourselves achieved with painful struggle for our own people; to share with us common responsibilities; to build your homes on our land without restriction as to how much of that land you can ultimately acquire for yourselves as individuals except the restrictions which are imposed by the system of justice which we will share and by the abilities of each individual; to make complete and unrestricted use of all our centres of learning and development; to accept the opportunity to gain for yourselves the highest offices in our country; to rest as securely under our protection as the most powerful and the most humble of our own people alike rest securely; to mix your blood with ours if you wish; to inherit with us everything of which we ourselves are the inheritors. ${ }^{36}$

He also assured his audience that 'You can preserve your traditions or national pride in any proper ways which seem fit to you'. ${ }^{37}$ In his speech, he mentioned neither Australian citizenship and the means of acquiring it nor a values statement that immigrants would be required to sign. He did not refer to the protracted process that is designed to select only the most

35 The following draws on Neumann, Across the Seas, 182-87, and Gil Marvel Tabucanon and Brian Opeskin, 'The Resettlement of Nauruans in Australia', Journal of Pacific History 46, no. 3 (2011): 337-56, doi.org/10.1080/00223344.2011.632992.

36 'Minutes of a special meeting of the Nauru Local Government Council with the Acting Administrator and D. McCarthy ... on Monday, 5th December, 1960', NAA A452, 1961/3157 PART 1, p. 6.

37 Ibid., p. 7. 
suitable among the refugees who want to settle in Australia. Instead he said: 'We ask you ... to become part of us and to allow us to become part of you'.

The Nauruans were then considered to be prospective environmental refugees (although that term was not yet being used). In more recent times, the Australian Government has rejected suggestions that it would be responsible for resettling Pacific Islanders - such as the inhabitants of the island nations of Nauru, Tuvalu and Kiribati - if they were to become displaced due to rising sea levels. Back in 1962, however, Australian Prime Minister Robert Menzies told Queensland Premier Frank Nicklin:

The availability of a source of cheap rock phosphate at Nauru has been of very great importance to the primary industries of Australia, the United Kingdom and New Zealand and there is a clear obligation on the Governments of these countries to provide a satisfactory future for the Nauruans. ${ }^{38}$

In 1963 the Menzies Government offered to resettle the Nauruans on Curtis Island, whose land area is well in excess of that of Nauru and which is within easy reach of the Queensland town of Gladstone. The government was not deterred by opposition to its plans from both Australians then living on Curtis Island and the Queensland Government. It was not swayed either by the prospect of breaching the then still sacrosanct White Australia policy. The following year, Cabinet authorised the purchase of Curtis Island, and agreed that the Commonwealth's powers under sections 51 and 52 of the Constitution be used to acquire the land if the Queensland Government was not willing to sell it. The Nauruans, however, wanted more than the resettlement Dudley McCarthy had offered them: they also insisted on political sovereignty. This was not something the Menzies Government was willing to countenance, and therefore, much to its surprise, the deal fell through.

In 2004, the Melbourne Age published a feature article by writer and filmmaker Paul Berczeller that promised to tell 'the real story behind Steven Spielberg's The Terminal. ${ }^{39}$ In that film, Tom Hanks plays Viktor

38 Menzies to Nicklin, 22 January 1962, NAA A452, 1961/3157 PART 1.

39 Paul Berczeller, 'A Man in Limbo', Age, 13 September 2004, A3, 1 and 4-5. The Age feature was first published in the Guardian (Paul Berczeller, 'The Man who Lost his Past', Guardian, 6 September 2004, available at: www.theguardian.com/film/2004/sep/06/features.features11). 
Navorski, a citizen of the fictive Eastern European Republic of Krakhozia, who arrives at John F. Kennedy Airport in New York only to find that events in his home country have rendered him stateless, and prevent him from either returning home or entering the United States..$^{40}$ Navorski is then forced to spend nine months in the airport's transit area. The Age article revealed that the film was based on a real story, that of Iranian man Merhan Karimi Nasseri, who spent 18 years in the transit area of Charles De Gaulle Airport near Paris. ${ }^{41}$

Nasseri's story had been told many times before, in feature films, documentaries and magazine articles, including in Berczeller's own film From Here to Where. ${ }^{42}$ The Age editor responsible for placing Berczeller's article may not have remembered Nasseri's case; he obviously did not recall either that 13 years earlier another man had spent several months in the transit lounges of airports in Asia, Europe and South America because of a botched Australian attempt to deport him.

On 18 February 1991, the Australian authorities deported a Cuban national by the name of Francisco Vazquez, who, four years earlier, had been sentenced to two years in prison for assault. ${ }^{43}$ In one sense, the case - the criminal deportation of a non-citizen - is hardly noteworthy. But there were several complicating factors. First, Vazquez had been resettled in Australia as a refugee. Second, the Cuban authorities were unwilling to take him back. And third, Vazquez was fearful of being deported to Cuba. The immigration department, however, was not troubled by these complications. 'He was deported as a criminal and he has to take his chances', a spokesman for the department told a journalist. 'Deporting someone doesn't necessarily mean we deport them to another country. We put them on an aircraft and having left, the book is closed. ${ }^{34}$

40 The Terminal [film], directed by Steven Spielberg (United States of America: 2004).

41 The story has been told in: Sir Alfred Mehran and Andrew Donkin, The Terminal Man (London: Corgi, 2004).

42 From Here to Where [film], directed by Paul Berczeller (Netherlands, 2002). The first feature film about Nasseri appeared in 1993 (Tombés du ciel [film], directed by Philippe Lioret (France, 1993)).

43 The following draws on Klaus Neumann and Savitri Taylor, "He has to Take his Chances": The Resettlement of a Refugee in Australia and his Deportation to the Country he had Fled, 1980-1992', History Australia 16, no. 3 (2019): 459-79, doi.org/10.1080/14490854.2019.1636672.

44 Quoted in Janet Fife-Yeomans, 'Deportee Faces Life of Endless Airports', Sydney Morning Herald, 7 March 1991. 
Vazquez was booked to fly from Sydney to Havana via Singapore and Moscow. In Moscow, the authorities refused to let Vazquez board a plane to Cuba, and returned him to Singapore. The Australians then booked him on another flight to Havana, this time via Rome and Madrid. He got as far as Madrid, and then returned to Rome, where he was issued with a new ticket to Cuba, this time via Caracas. When that attempt also failed, the Italian authorities compelled Singapore Airlines to return Vazquez to Singapore, where he arrived on 2 March. He was not allowed to leave the airport, as the Singaporean immigration authorities did not deem him to possess the required travel document.

For the next four months, the Singaporean and Australian governments argued over whose responsibility Vazquez was. On 22 May, Singapore's immigration department instructed Singapore Airlines to return Vazquez to Australia. As the Australian Department of Immigration served notice on the airline 'not to move the aircraft unless Mr Vazquez "is on that plane for the purposes of his removal out of Australia", Singapore Airlines flew Vazquez back to Singapore on the same day. ${ }^{45}$

On 7 June, Singapore gazetted regulations that made it possible to ground a plane at Singapore Airport, if its captain refused to take on board a passenger whom the airline in question had previously brought to Singapore without authorisation. In Australia, both sides of politics were alarmed by the prospect that these regulations would be used to procure the return of Vazquez to Australia on a Qantas flight. On 13 June 1991, Shadow Minister for Immigration Philip Ruddock released a media statement in which he said:

This action by the Singaporean Government puts Australia's deportation laws at grave risk. There is a provision in our law for criminal deportation for those who are found guilty of serious offences committed here in Australia. If we are forced, by other countries, to accept them back into Australia, our whole system of control is jeopardised. ${ }^{46}$

At the time of passage of the Singaporean regulations, the Migration Amendment Bill 1991 was before the Senate, awaiting resumption of the second reading debate. According to Gerry Hand, the immigration

45 High Commission of the Republic of Singapore to Department of Foreign Affairs and Trade Canberra, 29 May 1991, Annex, NAA A9737, 1991/1765 PART 1.

46 Philip Ruddock, 'Double Jeopardy', media statement, 13 June 1991, available at: parlinfo.aph. gov.au/parlInfo/download/media/pressrel/HPR02004731/upload_binary/HPR02004731.pdf. 
minister in the Hawke Government, the new legislation was part of a 'continuing process of fine tuning the major and far-reaching reforms' made by the Migration Legislation Amendment Act 1989.47 The 1989 Act had replaced a system of largely discretionary decision-making to minimise the scope for judicial intervention.

The immigration department, after being made aware of Singapore's intention to return Vazquez, saw the opportunity to amend the Migration Amendment Bill then before parliament to have legislation in place designed to ensure his detention upon arrival in Australia. On 21 June, the second reading debate on the Migration Amendment Bill 1991 resumed in the Senate, with the government moving amendments in anticipation of Vazquez's return. The Explanatory Memorandum tabled with the Senate amendments justified them as follows:

The Government is ... concerned about certain persons who have been deported from Australia under the Act and who may be returned by the authorities of another country to Australia ... It is intended that these persons should not be capable of using judicial review to secure their release and entry into the Australian community. ${ }^{48}$

In the House of Representatives, Philip Ruddock announced that the federal opposition 'enthusiastically endorse[d]' the Senate amendments and the 'Government's intention to send a clear signal that Australia has control over its own borders' ${ }^{49}$ He also offered the opposition's support for further amendments 'to limit the capacity of the courts to make decisions in that area..$^{50}$ For the Australian Democrats, its leader Janet Powell also supported the amendments in recognition of the need for the Government to be in control of the question of who does or does not enter this country. ${ }^{51}$ The Bill was amended as proposed, and passed on 21 June.

When Singapore returned Vazquez to Australia on 9 July 1991, the new legislation allowed for Vazquez's detention until his departure from Australia. 'Technically, Mr Vazquez has not re-entered Australia',

47 CPD, Representatives, 17 April 1991, 2846 (Gerry Hand).

48 Supplementary Explanatory Memorandum, Migration Amendment Bill 1991.

$49 C P D$, Representatives, 21 June 1991, 5269 (Philip Ruddock).

50 Ibid., 5270.

$51 C P D$, Senate, 21 June 1991, 5294 (Janet Powell). 
a representative of the immigration department was quoted as saying. ${ }^{52}$ The government lobbied Spain, the United States and Venezuela to accommodate Vazquez, but its requests were knocked back. Vazquez himself unsuccessfully applied to be admitted for residence to Spain, Argentina, Uruguay, Costa Rica, Colombia and Ecuador. In September 1991 he went on hunger strike. He sent a note to his solicitor saying: 'I cry for help, can you save me?'53 She could not. In early 1992, the government was eventually successful in persuading Cuba to agree to the return of its citizen. On 21 February 1992, Vazquez flew out of Sydney on travel documents provided by Cuba, reaching Havana two days later.

There had been no public outcry when Vazquez was kept in prison for more than two years after serving his sentence, while the government was trying to secure his deportation, nor when he was deported in February 1991, and then returned to Long Bay Gaol in July 1991. His deportation in February 1992 was barely noted. His status as somebody who had come to Australia as a refugee seemed to amount to little, at least in public debate.

The story of Francisco Vazquez draws attention to an aspect of the prerogative that the government ought to decide whether a non-citizen may enter the country or remain in it, that has been comparatively uncontroversial. Vazquez's story would not easily lend itself to be turned into a Hollywood movie - or an ABC miniseries, for that matter. Yet from today's vantage point, the response to Vazquez is still surprising. He came to Australia as a refugee, and was to be returned to a communist country at a time when the Cold War was not yet just a distant memory. Is it not surprising that his case - and, in particular, the amendment of legislation specifically to ensure that he could be detained indefinitely and that his detention could not be challenged in the courts - did not attract more attention at the time? Is it not equally surprising that Australians may know about Merhan Nasseri, but have never heard about Vazquez?

From today's vantage point, the single-mindedness with which the Hawke Government prosecuted the Vazquez case may also come as a surprise, given that the dictum 'we decide who comes to this country and the circumstances under which they come' is nowadays mostly traced back to

52 Jennie Curtin, 'Jail is the Only Place that will take Deportee', Sydney Morning Herald, 10 July 1991.

53 Janet Fife-Yeomans, 'Globetrotter Deportee on Food Strike', Sydney Morning Herald, 11 September 1991. 
John Howard's pitch to voters during the 2001 federal election campaign, and the origins of Australia's current border control policies tend to be associated with Hawke's successor Paul Keating, if not, once again, with the Howard Government's response to the arrival of the Tampa off Christmas Island. Vazquez's story makes it more difficult to think of current Australian Government policies as an anomaly that began in 2001.

All three stories have the potential to unsettle views of the past and the present that are indebted to a notion of history whereby past, present and future are on a linear trajectory, and which assume that there is an inexorable progression along that trajectory.

The past-becomes-the-present-becomes-the-future variety of history privileges pasts that can be seen to form the nucleus of the present. Not only does such history pay scant attention to presumed cul-de-sacs, it is also often content with truncated genealogies that ostensibly suffice to establish how the present came into being. At the end of the day, a history that does only that risks becoming an apology of the present. A history that does only that makes it harder for us to envisage futures that are not already contained in the present. Some pasts are ostensibly inconsequential in that they did not turn into the present. But these 'dead ends', once rendered as history, might retain some currency. In my previous work about postcolonial histories in Papua New Guinea, I termed accounts of such pasts 'the trash of history'. ${ }^{54}$ Such trash can be unwieldy, awkward, even subversive.

In grand narratives that chart Australian history from the Immigration Restriction Act 1901 via the Tampa affair to the creation of the Department of Home Affairs in 2017, or from the arrival of 843 Displaced Persons aboard the Heintzelman in 1947 via the resettlement of Indochinese refugees in the late 1970s and early 1980s to the Abbott Government's decision in 2015 to admit an additional 12,000 Syrian and Iraqi refugees,

54 Klaus Neumann, 'Starting from Trash', in Remembrance of Pacific Pasts: An Invitation to Remake Histories, ed. Robert Borofsky (Honolulu: University of Hawai'i Press, 2000), 62-77, doi.org/ 10.1515/9780824864163-006. 
the Menzies Government's invitation to the Nauruans to settle in Australia, as a group, preserving their 'national pride', with all the rights and privileges of Australian citizens, constitutes precious trash.

The three stories I told could be interpreted as attempts to set the record straight. They could be seen as attempts to point out that in order to understand Australia's response to the refugee crisis in 1938 we ought to focus on Bruce's politicking behind the scenes, rather than White's infamous line; that we ought to be wary of accounts that don't accord agency to the Nauruans; and that deportation policies and practices in the late 1980s and early 1990s may tell us as much about border protection as the introduction of mandatory detention and the Tampa affair.

Yet this is not simply an argument for more nuanced accounts. Not least Australia's history wars taught me that a dispute over what happened, based on an interpretation of 'historical evidence', may well be counterproductive - unless it is accompanied by a discussion about what history is, how it produces truth effects, what it is for, who benefits from it and why it is done. ${ }^{55}$ When contributing to such a discussion, historians may want to reflect on how they respond to public expectations about the usefulness of their craft. Are they perhaps too readily drawing lessons, explaining the present or writing accounts that could easily be slotted into patriotic narratives of the nation?

Personally, I wish that disputes over what happened - for example, over the precise number of Indigenous people killed by European settlers in Van Diemen's Land - were accompanied by the search for a historical practice that does not shore up the present but that produces histories that are unsettling, disrupting notions of a seamless progression from the status quo ante to the status quo. Such histories may even allow for futures to be imagined that are not yet contained in the present, and which are attentive to pasts that did not culminate in the present.

55 This is not the place to revisit the issue of the history wars, during which many of Keith Windschuttle's opponents too readily accepted his premises about how historical truth is produced. See Klaus Neumann, 'Among Historians', Cultural Studies Review 9, no. 2 (2003): 177-91. 
This text is taken from Refugee Journeys: Histories of Resettlement, Representation and Resistance, edited by Jordana Silverstein and Rachel Stevens, published 2021 by ANU Press, The Australian National University, Canberra, Australia.

doi.org/10.22459/RJ.2021.10 